\title{
Difficulties in the Treatment of Urinary Tract Stone Disease in Physically Disabled Patients: Report of Two
}

\section{Cases}

\section{Fiziksel Engelli Hastalarda Üriner Sistem Taş Hastalığının Tedavisinde Yaşanan Zorluklar: Iki Olgu Sunumu}

Olgu Sunumu Case Report

Received/Geliş: 01.03.2019 Accepted/Kabul: 07.03.2019 Published Online: 05.01.2021

Mehmet Yiğit Yalçın SBÜ, Tepecik Eğitim ve Araştırma Hastanesi, Üroloji Kliniği, Izmir - Türkiye yigityalcin@hotmail.com ORCID: 0000-0001-9943-7453

M.H. Özbilen 0000-0002-5733-6790 M.Z. Keskin 0000-0002-9206-5586 Y.ö. Illbey 0000-0002-1483-9160 SBÜ,Tepecik Eğitim ve Araştırma Hastanesi, Üroloji Kliniği, Izmir, Türkiye

Cite as: Yalçın MY, Özbilen MH, Keskin MZ, Cite as: Yalçın MY, Ozbilen $M H$, Keskin $M Z$. Difficulties in the treatment of uri-
ilbey nary tract stone disease in physically disabled patients: Report of two cases. Tepecik Eğit. ve Araşt. Hast. Dergisi. 2020;30(3):311-5.

\author{
Mehmet Yiğit Yalçın $\odot$, Mert Hamza Özbilen®, Mehmet Zeynel Keskin $\odot$, \\ Yusuf Özlem İlbey $\odot$
}

\begin{abstract}
Urinary stone disease is a very common disease in our country. Some problems may be experienced in stone surgery of physically disabled patients. This special patient group may require both minimally invasive and open stone surgery techniques. In this study, the difficulties encountered in the surgery of two physically disabled patients who were operated for stone disease were shared.
\end{abstract}

Keywords: Nephrolithiasis, Physically disabled patient, stone surgery

Öz

Üriner sistem taş hastalığı, ülkemizde oldukça sık görülen bir hastalıktır. Fiziksel engelli hastaların taş cerrahisinde bir takım sorunlar yaşanabilmektedir. Bu özel hasta grubuna gerek minimal invaziv, gerek açık taş cerrahisi teknikleri gerekebilir. Bu çalışmada, taş hastalığı nedeniyle opere edilen fiziksel engelli iki hastanın cerrahisinde karşılaşılan zorluklar paylaşıldı.

Anahtar kelimeler: Nefrolitiazis, Fiziksel engelli hasta, taş cerrahisi

\section{INTRODUCTION}

Patients with severe physical disabilities may pose difficulties in obtaining appropriate position to direct the urological equipment for stone surgery. Congenital or acquired musculoskeletal abnormalities complicate the applicability of endoscopic urological stone surgeries. Impaired anatomy of the patients and changes in the chest wall make breathing difficult which create difficulties for both the anesthetist and the surgeon ${ }^{(1)}$. In this study, we aimed to share the difficulties encountered in the surgery of two physically disabled patients who applied to our clinic due to urinary stone disease.

\section{CASE 1}

A 41-year-old immobile female patient with dysuria and left-sided pain for 4 months was examined. Noncontrast abdominal computerized tomography (CT) revealed a staghorn stone filling all calyceal system of the left kidney with dimensions of $30 \times 40 \times 50 \mathrm{~mm}$ and a stone measuring $15 \times 13 \times 20 \mathrm{~mm}$ in the right renal pelvis (Image 1). Our patient had a history of

(C) Telif hakkı T.C. Sağılık Bakanlığı İzmir Tepecik Eğit. ve Araşt. Hastanesi. Logos Tıp Yayıncılık tarafindan yayınlanmaktadır. Bu dergide yayınlanan bütün makaleler Creative Commons Atff-GayriTicari 4.0 Uluslararası Lisansı ile lisanslanmıştır.

(c) Copyright Association of Publication of the T.C. Ministry of Health İzmir Tepecik Education and Research Hospital. This journal published by Logos Medical Publishing. Licenced by Creative Commons Attribution-NonCommercial 4.0 International (CC BY) 


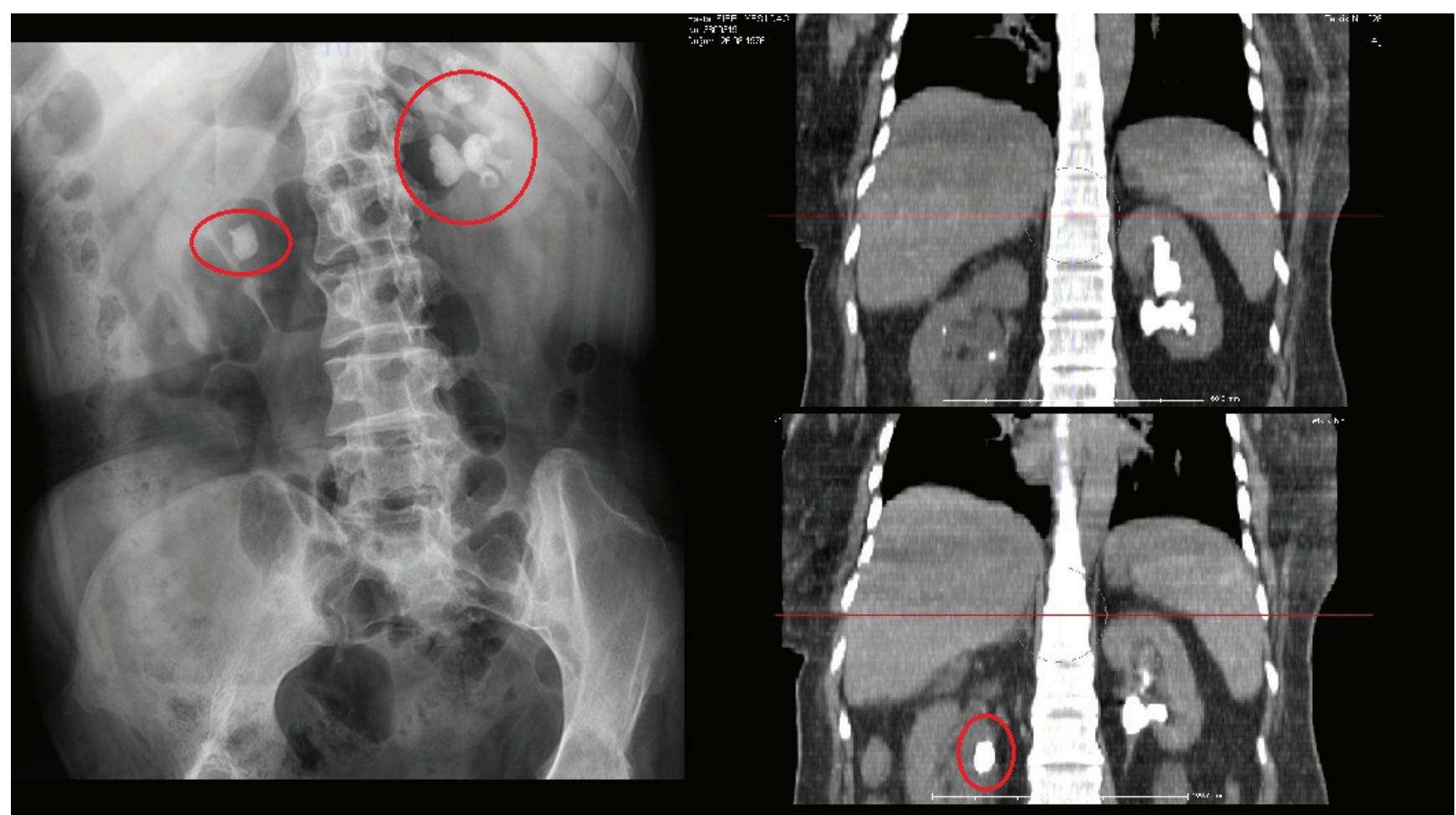

Image 1. Staghorn stone opacity that fills all calyceal system in the left kidney and $\mathbf{2} \mathrm{cm}$ stone in the right kidney.

hypoxic encephalopathy due to choking. There were flexion contractures in all extremities, especially in the lower extremities. Left percutaneous nephrolithotomy (PNL) was planned if the prone position could be given and right retrograde intrarenal surgery (RIRS) was planned in the same session for the patient who completed preoperative preparations and had no bacterial growth in urine culture. The patient's hip and other lower joint contractures were evaluated again under general anesthesia. A modified lithotomy position was given to patient by considering the contracture angles so as to allow maneuvering of flexible ureterorenoscope by the surgeon. The patient's body was supported with silicone pads in order to protect the patient from bed sores. The patient underwent right RIRS without any problem. Due to flexion contracture of the entire lower extremity, image superposition under scopy, risk of bone fracture and respiratory problem reported by anesthetist, prone position could not be given to the patient and the PNL procedure planned on the left side could not be performed. For this reason, RIRS was applied in the modified lithotomy position to the left kidney. The stones in the left renal pelvis and upper pole were fragmented. Second RIRS session was planned for the stones in the middle and lower pole due to stone burden and prolonged operation time. Bilaterally double J stents were inserted and the operation was terminated. Postoperative 1st month follow-up CT revealed stone-free status in the right kidney, residual stones in the lower and middle poles and stone fragments in the upper pole of the left kidney. The second RIRS session was performed in the postoperative 2 nd month. In the postoperative period, she was followed up for one day in the intensive care unit for observation. Antibiotherapy was started because of fever and urinary infection caused by Escherichia coli. The patient was discharged on the seventh postoperative day. Her postoperative imaging could not be seen because the patient was out of follow-up. 


\section{CASE 2}

A 53-year-old male patient who was under follow-up for postoperative chemoradiotherapy due to gastric cancer applied to our clinic upon detection of ureter stone on non-contrast abdominal computerized tomography (CT). Non-contrast abdominal CT revealed $12 \times 10 \times 18 \mathrm{~mm}$ stone at the right iliac brim and hydronephrosis was detected proximal part of the stone. The patient had the diagnosis of ankylosing spondylitis (AS) for 20 years, and followed by rheumatology department and received multiple treatment. On physical examination, the pelvis and columna vertebralis were in neutral position and cervicalhip-knee joint could not perform flexion-extensionadduction-abduction movements. On CT image (image 2), arthrosis of the facet joints in the vertebrae, the presence of ossification in the interspinous ligaments, and the fusion of the sacroiliac joints were detected. The anesthetist was informed by the rheumatologist that hyperextension should be avoi- ded because of the cervical involvement of AS. The patient was prepared for tracheostomy by considering the possibility of difficult intubation and necessity of tracheostomy. The patient who had no bacterial growth in urine culture was taken into operation. The patient's body was supported with silicone pads to protect against pressure on the operating table. Flexible ureteroscopy was tried in supine position butcould notbedirected to thestone. Anesthesiologist stated that the patient could not tolerate this procedure with higher respiratory risk due to increased intra-abdominal pressure for laparoscopic ureterolitotomy. Thereafter, an open ureterolithotomy was performed. There were no complications during intraoperative or postoperative period. Drainage tube was removed on postoperative $2^{\text {nd }}$ day and the patient was discharged.

\section{DISCUSSION}

Urinary system stone disease is a very common dise-

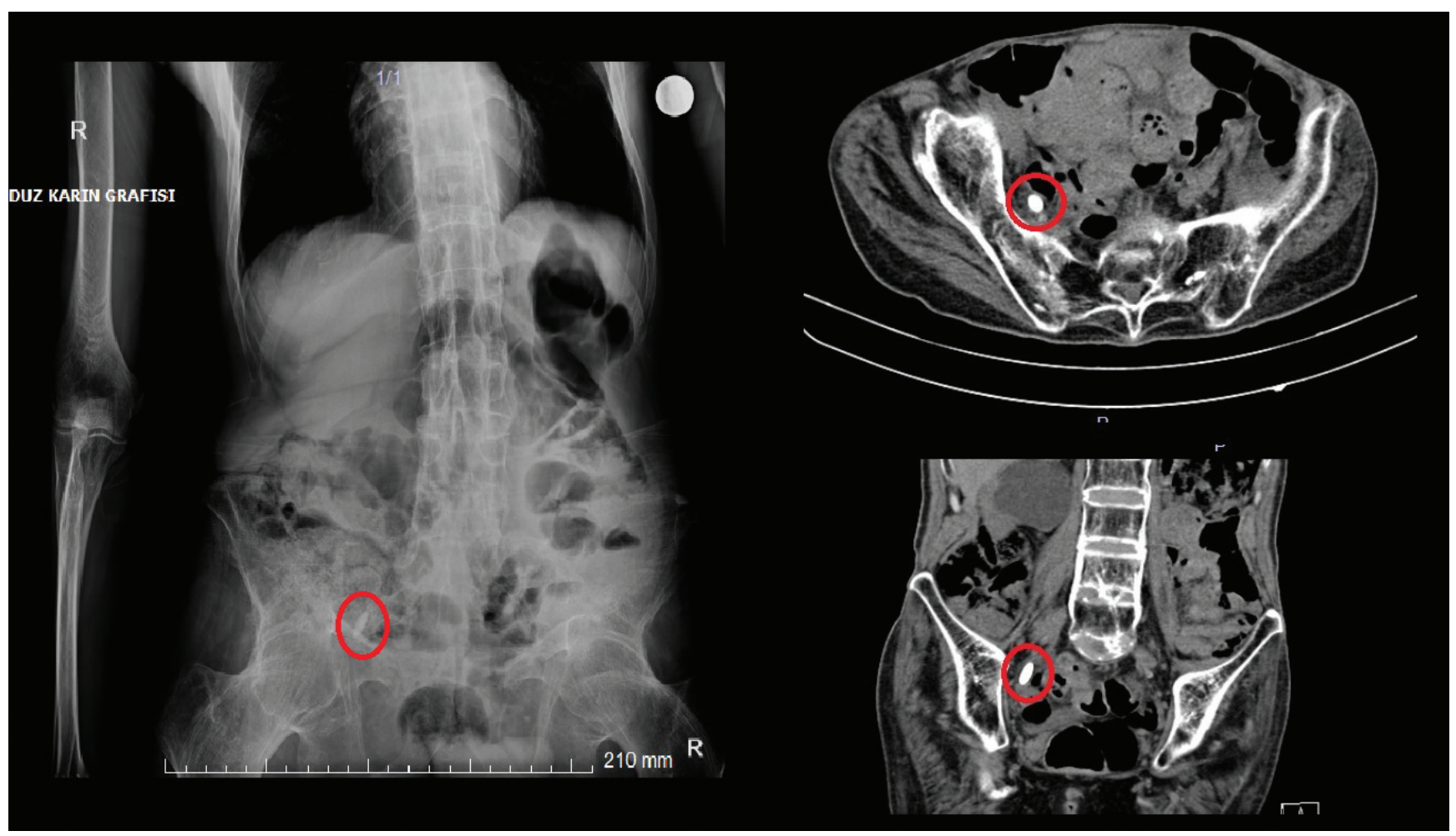

Image 2. Bamboo spine appearance due to ankylosing spondylitis in vertebrae, fusion in sacroiliac joints, ureteral opacity on right iliac brim level. 
ase. The prevalence of urinary stone disease in our country is higher than western society ${ }^{(2)}$. In the current management of urinary system stones followup, medical therapy, extracorporeal shock wave lithotripsy (ESWL), PNL, RIRS, laparoscopy/robotassisted and open surgery should be considered.

Open stone surgery was the only treatment option despite high morbidity and complications before PNL and ESWL were introduced ${ }^{(3)}$. With the use of ESWL, treatment with lower morbidity has emerged. However, success rates were lower in patients with high stone burden. While the patient-related position problem was a challenge for ESWL, stone-free rates were also lower due to restricted mobility ${ }^{(4)}$. For this reason, ESWL has not been a successful treatment option in patients with deformity and decreased physical activity who are almost impossible to be positioned. Therefore, ESWL was not applied in both of our cases. At the same time, in the postoperative imaging of the Case 1 , residual stone fragments were seen in the upper pole of the left kidney due to immobilization.

Thanks to advances in endoscopic approaches together with the developing medical technology; in most of the patients who have kidney stones, minimally invasive treatments are used and the need for open surgery in the special group of patients as in our physically handicapped patients is required in 1-2\% of the cases ${ }^{(5,6)}$.

Congenital conditions such as congenital spinal deformity, congenital kyphoscoliosis, cerebral palsy, hypoxic ischemic encephalopathy or acquired conditions such as previous trauma and musculoskeletal anomalies secondary to operations may lead to difficulties for the operational positioning and surgeons. In Case 1, it was possible to perform the operation with supine PNL technique. However, the patient did not want to go to the center where supine PNL technique was applied due to social reasons. Prone PNL could not be performed due to joint contractures, continued risk of bone fracture despite supportive silicone pads and respiratory problem. Two sessions of RIRS were performed for the patient.

In the group of physically disabled patients, due to chest wall and costal deformities lung volumes are limited, dead space ventilation is increased, tidal volumes and expiratory capacities are low. This condition places the patients in the high risk respiratory group peroperatively and postoperatively (7). Therefore, hypoventilation may cause problems in anesthesia. The anesthetist should evaluate the patient's respiratory status very well peroperatively and should possibly recommend intensive care treatment for the patient. In our Case 2, open surgery was performed after the failed RIRS procedure because the patient's respiratory status was not suitable for laparoscopic surgery. In the preoperative period, the patient should be evaluated with the cooperation of anesthesia, radiology, ear-nose-throat and chest diseases and should be prepared for tracheostomy, and treatment in the intensive care unit. Because of the limited hyperextension of the neck in the case of AS, the patient was taken to the operation, and prepared for tracheostomy.

In the literature, the case series of urinary stone surgery are limited in the physically disabled patient group. These patients are challenging for both the surgeon and the anesthetist. Preoperative evaluation of the cases and selection of appropriate patientoperation technique is important. As seen in these two cases, minimally invasive stone surgery techniques can be used safely in patients with physical disabilities and open stone surgery may be necessary if minimal invasive stone surgery is not possible/ suitable.

Conflict of Interest: None.

Informed Consent: Informed consent form was obtained from the patient. 


\section{REFERENCES}

1. Kundra P, Joseph A, Kumar S. Double-lumen tube for ventilation in severe kyphoscoliosis J Anesth. 2008;22:317-21. [CrossRef]

2. Pearle MS LY. Urinary lithiasis, etiology, epidemiology, and pathogenesis. In: Editor-in-chief, editor. Campbell-Walsh Urology. $10^{\text {th }}$ ed ed: Elsevier Saunders. 2012. p. 1257-87. [CrossRef]

3. Argyropoulos AN, Wines M, Tolley D. Case report: en-dourologic treatment for a ureteral stone in a patient with osteogenesis imperfecta. J Endourol. 2008;22:459-61.
[CrossRef]

4. Lazare JN, Saltzman B, Sotolongo J. Extracorporeal shock wave lithotripsy treatment of spinal cord injury patients. J Urol. 1988:140;266-9. [CrossRef]

5. Matlaga BR, Assimos DG. Changing indications of open stone surgery. Urology. 2002;59(4):490-3; discussion 3-4. [CrossRef]

6. Kane CJ, Bolton DM, Stoller ML. Current indications for open stone surgery in an endourology center. Urology. 1995;45(2):218-21. [CrossRef]

7. Chan G, Dormans JP. Update on congenital spinal deformities: preoperative evaluation. Spine 2009;34:1766-74. [CrossRef] 